\title{
Povolání chirurg: \\ pohled pod povrch profese očima chirurgů ${ }^{1}$
}

\author{
Vlastimil Švec ${ }^{1}$, Teodor Horváth², \\ Petr Moravčík², Markéta Španková2, \\ Zdeněk Kala² \\ ${ }^{1}$ Masarykova univerzita, Pedagogická fakulta \\ 2 Masarykova univerzita, Lékařská fakulta
}

\begin{abstract}
Abstrakt: Studie je sondou do profese chirurga pohledem chirurgů. Představuje kvalitativní design výzkumu vycházející z naturalistické tradice, založený na polostrukturovaných rozhovorech s chirurgy. Odpovídá na čtyři výzkumné otázky: 1) Které předpoklady pro chirurgickou profesi považují chirurgové za důležité? 2) Jak se mladí chirurgové učí chirurgii? 3) Které zdroje svého profesního růstu chirurgové uvádějí? 4) Jak (ze charakterizovat proces profesního růstu chirurga? Takto vznikly čtyři soubory odpovědí, které byly dále analyzovány z hlediska jejich obsahu. Postupně byly získány menší soubory zahrnující významově podobné odpovědi. Tyto soubory byly označeny kategoriemi, které tvoři jádro interpretací. Jedním ze zajímavých a zároveň významných výsledků výzkumu je návrh desetistupňového modelu profesního růstu chirurga: 1) řemeslo, 2) pravidla, 3) růst, 4) variace, 5) tvořivost, 6) mistrovství, 7) souhra, 8) součinnost, 9) služba, 10) naplnění. Studii lze považovat za př́klad mezioborové spolupráce pedagoga a chirurgů.
\end{abstract}

Klíčová slova: profese chirurga, kvalitativní výzkum, polostrukturovaný rozhovor, předpoklady pro profesi chirurga, učení mladého chirurga, profesní růst chirurga, mezioborová spolupráce

\section{The Surgeon's Occupation: Surgeons Look Beneath the Surface of Their Profession}

Abstract: This study is a probe into the surgical profession from the surgeons' perspective. It presents a qualitative research design drawing from the naturalist tradition based on semi-structured interviews with surgeons. It answers four research questions: 1) Which prerequisites for the surgical profession do surgeons consider important? 2) How do young surgeons learn surgery? 3) Which sources of their professional growth do surgeons note? 4) How can the process of professional growth of a surgeon be characterized? The research questions were a starting point for the analysis of surgeons' answers. Four sets of surgeons' answers were obtained so that their content could be analyzed. Gradually, four smaller sets including answers with similar meaning were obtained. These sets were marked with categories forming the core of interpretations. Research results were organized in accordance with the research questions. One of the most interesting as well as important research results is the design of ten-grade model of surgeons' professional growth including the following ten grades: 1) craft, 2) rules, 3) growth, 4) variation, 5) creativity, 6) mastery, 7) coordination, 8) collaboration, 9) service, 10) fulfilment. The study can be regarded as an example of interdisciplinary collaboration between a teacher and surgeons.

Keywords: surgical profession, qualitative research, semi-structured interview, prerequisites for the surgical profession, learning of a young surgeon, surgeons' professional growth, interdisciplinary collaboration

1 Studie byla zpracována $v$ souvislosti s řešením projektu „Proměny ve výchově a vzdělávání jako výzva pro pedagogické profese“ (MUNI/A/1233/2018).

https://doi.org/10.14712/23363177.2019.20

www.orbisscholae.cz

(c) 2019 The Authors. This is an open-access article distributed under the terms of the Creative Commons Attribution License (http://creativecommons.org/licenses/by/4.0), which permits unrestricted use, distribution, and reproduction in any medium, provided the original author and source are credited. 
108 V současné době lze v zahraničí i v České republice sledovat zájem o pomáhající profese (např. zdravotnické, pedagogické, ze sociální oblasti a další). Pomáhající profese zahrnují povolání, která jsou „založená na profesní pomoci druhým lidem“ (Géringová, 2011, s. 21). Profesi chirurga lze zařadit do pomáhajících profesí. Pomoc chirurga je na pacientovi obvykle velmi rychle vidět - dochází k uzdravení nebo zlepšení kvality života. Jindy zase život pacienta, a to právě v souvislosti s operací, visí na vlásku a výjimečně může v souvislosti s ní skončit dříve než bez ní, anebo se kvalita jeho života po operaci zhorší. Profesi chirurga si volí absolvent lékařské fakulty. $V$ průběhu studia absolvuje také chirurgickou propedeutiku, avšak s podrobnějším popisem profese chirurga se obvykle nesetkává. Schází její podrobnější zmapování, aby bylo možné do chirurgie přesvědčivěji zasvěcovat mladé lékaře a také $z$ nich vybírat nejvhodnější kandidáty pro tento náročný obor.

V Institutu výzkumu školního vzdělávání PdF MU jsme v roce 2017 zahájili studium pomáhajících profesí. Rozvijí zde svoji činnost Stálý interdisciplinární seminář k profesím a profesní prípravě, kterého se dosud účastní především zástupci pomáhajících profesí z různých fakult $M U$. Jeho účastníci se snaží odpovědět napríklad na otázky: Jak se člověk stává profesionálem? Jak se profese formují a proměňují? Jakou roli hraje př́prava na profesi? Jak jsou do profese uváděni novicové? Jeden z účastníků semináře, povoláním vysokoškolský učitel, orientovaný na problematiku učitelského vzdělávání a jeho výzkum (dále pedagog, spoluautor této studie), se začal výzkumně zabývat profesí chirurga. Jeho zájem o lékařskou profesi vznikl již na střední škole, kde se po maturitě rozhodoval mezi studiem učitelské profese a studiem medicíny. Zvolil učitelské studium, ale o medicínu se nepřestal zajímat.

\section{Východiska zkoumání profese chirurga}

V Encyklopedii profesí (www.prace.cz/encyklopedie-profesi/ch/chirurg) je o profesi chirurga uvedeno:

Chirurg je lékař, který léči různá onemocnění nebo zranění operativně manuálním nebo instrumentálním ošetřením. Do jeho pracovní náplně patři diagnostika postižení, stanovení operativního postupu, operace (chirurgický zákrok) a pravidelná péče o pacienta po operaci. K výkonu povolání je potřeba vysokoškolské vzdělání lékařského směru.

Toto spiše normativní vymezení poskytuje obecný a povšechný pohled na profesi chirurga. V České republice nebyla dosud profese chirurga zkoumána, Při hledání zahraničních studií o profesi chirurga a jejím výzkumu jsme v databázi Web of Science (klíčové slovo „profese chirurga“ v kombinaci se slovy „teorie“ a „výzkum“) našli za období let 2000-2017 texty zabývající se specifickými otázkami chirurgie a její výukou, $\mathrm{k}$ teorii profese chirurga a výzkumu profese chirurga nebyly nalezeny relevantní zdroje. 
Zjišt'ovali jsme, zda se bude možné oprít o určitou teorii profesí. V českých zdrojích dominují sociologické teorie profesí. Také Křížová (2006) nahlíží proměny lékařské profese ze sociologického hlediska. Schází pedagogické teorie profesí, které by si všímaly například předpokladů pro profesi, přípravy na profesi a profesního růstu profesionálů. Někteří autoři si zřejmě uvědomují nedostatek literatury k teorii jednotlivých profesí i absenci obecnější mezioborové teorie profese. Doporučují začít zkoumat obsahové jádro profesí a využít při tom kvalitativní studie (Nolin, 2008). Kvalitativní výzkum umožňuje profesím lépe porozumět a tím přispět k zvýšení kvality praxe profesionálů (ibid., s. 49).

I na základě uvedené inspirace jsme se rozhodli začít zkoumat profesi chirurga z pedagogického hlediska. Zaměřili jsme se na předpoklady pro chirurgickou profesi a na profesní učení a profesní růst chirurgů. Při promýšlení metodologie výzkumu jsme došli k závěru, že bude užitečné se ptát na chirurgickou profesi přímo chirurgů. Byli jsme si vědomi skutečnosti, že již existují biografie a autobiografie význačných českých (československých) chirurgů (např. Balaš \& Vlček, 1998; Hájek, 2011; Hoch, 2007; Nahodil, 2017; Pafko, 2004; Procházka, 1989). Jde v nich vesměs o jejich výpovědi či sdělení jejich žáků. Z publikací se lze dozvědět o jejich životě a práci i o problémech, s nimiž se ve své profesi setkali. Nicméně systematičtější pohled na chirurgickou profesi mohou přinést rozhovory s chirurgy, i když se lze opírat o zmíněné biografie a autobiografie. Uvědomili jsme si také, že bez spolupráce s chirurgy nebude možné jejich profesi zkoumat. Nešlo jen o předpoklad, že chirurgové a jejich práce budou předmětem výzkumného zájmu, ale i o to, že někteří z nich (spoluautoři této studie z Chirurgické kliniky Lékařské fakulty MU) budou tento výzkum podporovat a konzultovat jeho průběh a výsledky.

\section{Metodologie}

Cílem výzkumu bylo zjistit na základě výpovědí chirurgů, které předpoklady považují pro chirurgickou profesi za důležité, jak vidí učení mladých chirurgů a které zdroje jim pomáhají profesně růst. Z cíle vyplynuly tyto výzkumné otázky:

1) Které předpoklady pro chirurgickou profesi považují chirurgové za důležité?

2) Jak se mladí chirurgové učí chirurgii?

3) Které zdroje svého profesního růstu chirurgové uvádějí?

Bezprostředně po zahájení výzkumu jeden z chirurgů, spoluautor této studie, motivován zřejmě otázkami, které mu v rozhovoru kladl pedagog, přišel s návrhem uvažovat o chirurgické profesi také z hlediska procesuální stránky profesního rưstu chirurga a pokusit se rozlišit $v$ tomto procesu určité etapy. Vycházel z dlouholetých osobních zkušeností i zájmu o profesi chirurga. Tak vznikla dodatečně čtvrtá výzkumná otázka:

4) Jak lze charakterizovat proces profesního růstu chirurga?

Z výzkumných otázek je zřejmé, že k jejich zodpovězení bude vhodný kvalitativní výzkum. V něm se hlásíme $k$ naturalistické tradici, která (mimo jiné): a) chápe 
110 výzkumníka a zkoumané osoby jako kličcoé výzkumné nástroje, b) se orientuje na záměrný výběr, c) předpokládá, že dopředu není známa přesná podoba dat, d) hranice výzkumu se postupně utvářejí na základě jeho zaměření (Barber \& Brownell, 2011, s. 76). Jako výzkumný nástroj jsme využili polostrukturovaný rozhovor, který umožňuje pružnou interakci mezi výzkumníkem a zkoumanými osobami. Jeho základem jsou rámcové otázky, které pedagog $v$ průběhu rozhovoru doplňoval dalšími otázkami tak, aby se dostal co nejbliže chirurgovu uvažování. Snažil se porozumět žité zkušenosti jedince. Tuto zkušenost lze považovat za výsledek společného sdílení výzkumníka (pedagoga) a dotazovaného jedince (Koutná Kostínková \& Čermák, 2013, s. 11).

Výběr vzorku chirurgů byl záměrný. Vycházeli jsme z předpokladu, že zdrojem dat o chirurgické profesi budou výpovědi chirurgů opírající se o jejich zkušenosti, a to $z$ různých pracovišt' v ČR, různého věku a pohlaví (chirurg/yně). Oslovili jsme všeobecné chirurgy z chirurgických pracovišt' v Brně, Praze a Zlíně, kteří s rozhovory souhlasili. Vzorek patnácti chirurgů zahrnoval:

- čtyři začínající chirurgy před chirurgickou atestací (chirurg A - Brno, chirurgyně B - Brno, chirurgyně C - Brno a chirurg D - Zlín);

- chirurga necelý rok po atestaci (chirurg $\mathrm{E}-\mathrm{Brno}$ );

- pět atestovaných, již zkušených chirurgů (chirurg $F-B r n o$, chirurgyně $G-B r n o$, chirurgyně $\mathrm{H}$ - Brno, chirurg $\mathrm{CH}$ - Praha, chirurg I - Zlín);

- pět chirurgů $s$ velkými zkušenostmi, na vrcholu chirurgické dráhy (chirurg $\mathrm{J}$ Brno, chirurg K - Brno, chirurg L - Praha, chirurg M - Praha, chirurg N - Zlín).

Otázky rozhovorů vycházely z výzkumných otázek. Pro ilustraci uvádíme př́klady některých startovacích otázek kladených $v$ polostrukturovaných rozhovorech chirurgům: Co pro vás znamená, když se řekne dobrý chirurg? Dá se chirurgie naučit? Jak se učí mladí chirurgové? Co vás nejvíce posouvalo v chirurgické erudici? Stane se i dnes, že vás jako zkušeného chirurga něco překvapí? Rozhovory se uskutečnily od záŕi 2017 do července 2018. Vedl je pedagog, který pořizoval jejich zvukový záznam. Záznam rozhovoru ( $v$ délce zhruba 1-1,5 hodiny) pak doslovně přepsal do textové podoby $k$ další analýze.

Pedagog a čtyři chirurgové průběžně sdíleli výsledky výzkumu (rozhovorů). Z obrázku 1 je zřejmé, že předpokladem účelného sdílení je vnitřní motivace pedagoga a chirurgů vzájemně při výzkumu spolupracovat. Do sdílení přinášel pedagog nejen svůj zájem o profesi chirurga, ale i z něho vyplývající orientaci v této profesi, získanou studiem biografií a autobiografií chirurgů a orientačními rozhovory $\mathrm{s}$ jinými chirurgy o jejich práci ještě před vlastním výzkumem. Na druhé straně chirurgové při sdílení poznávali, jak pedagog uvažuje jako výzkumník. Zřejmě je motivovalo také to, že o jejich profesi projevil zájem představitel jiné profese. 


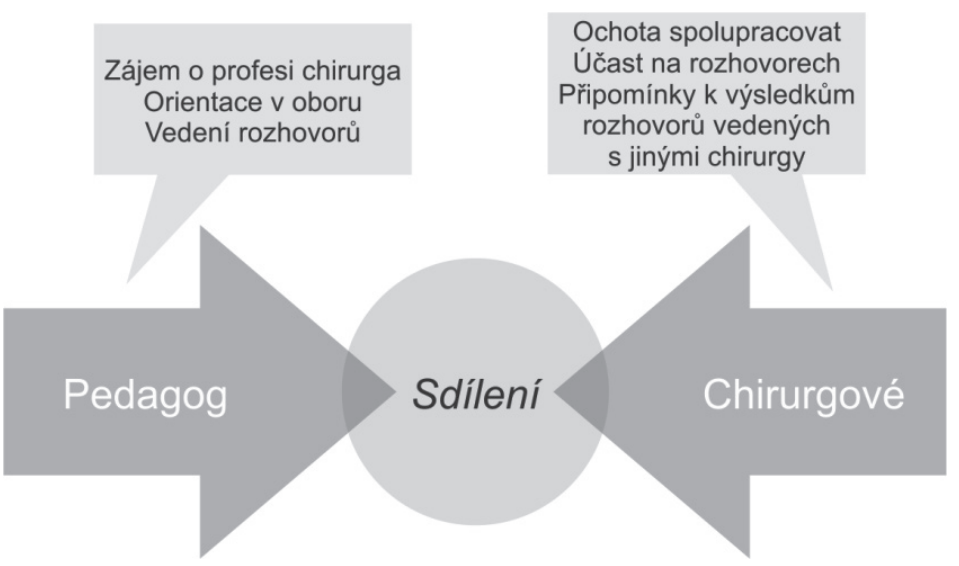

Obrázek 1 Sdílení poznatků mezi pedagogem a chirurgy v průběhu výzkumu

\section{Analýza dat a výzkumná zjištění}

Textové přepisy rozhovorů pedagog rozdělil na malé segmenty. Každý segment obsahoval otázku a odpověd' chirurga. Tyto segmenty nejdříve seskupil, aby jejich obsah korespondoval s výzkumnými otázkami. Získal tím čtyři soubory segmentů. Uvnitř každého souboru hledal segmenty s podobným obsahem. Vzniklé podsoubory označil názvy tak, aby vystihovaly obsah segmentů. Každý podsoubor podrobil další obsahové analýze s cílem nalézt menší významově samostatné skupiny. Ty také označil názvem. Takto vytvořil třiúrovňovou osnovu pro uspořádání výzkumných dat i strukturaci textu této studie (viz príloha).

$V$ další části studie uvedeme výzkumná zjištění, která jsou výsledkem nastíněné analýzy obsahu odpovědí chirurgů. Odpovědi (výroky) chirurgů jsou psány kurzivou. Za výroky jsou v závorce uvedena dvě písmena: první (Ch) označuje, že jde o odpověd’ chirurga, druhé (různá velká písmena) označuje konkrétního chirurga (viz popis vzorku v kapitole 2).

\subsection{Chirurgovy předpoklady pro jeho úspěšnou činnost}

Základní psychomotorické schopnosti a dovednosti. Za základní psychomotorické schopnosti a dovednosti považují dotázaní chirurgové zručnost, prostorovou představivost a citlivost k tkáním. Chirurg by měl mít určitou zručnost. (Ch N) Manuální zručnost chirurgové spojují s prostorovou představivostí. Chirurg musí mít velkou prostorovou predstavivost, protože $v$ té dutině břišní se jinak neorientujete. Chirurgie i ta traumatologie, to je o tom prostoru, musite si to představit z různých pohledů. (Ch C) Je to prostorová představivost, podobná jako možná u architektů. Umět si představit prostorové, jak to bude vypadat. Protože ono to asi nejde namalovat, umět si představit, jak to tam asi je, kam se dostanu. (Ch I) 
Prostorová představivost je založena také na schopnosti vizualizovat různé situace a způsoby jejich řešení. Ta vizualizace, to je neskutečný dar, to říkal Einstein. Když problém vizualizujeme, tak jsme schopni ho nějakým způsobem vyřešit. Já si to musím nějakým způsobem představit, co tam najdu... (Ch G) Mně vizuální pamět', se kterou se člověk narodí, hodně pomáhala na medicíně, v té chirurgii, protože já jsem schopen si to predstavit i z druhý strany, jinak, než je to nakresleno $v$ té knižce. Ale když se na to dívám, tak vidím, jak je to zezadu. Když to kolegové nemají, tak jim to trvá hrozně dlouho, než si to okoukají. (Ch M)

Chirurg při operaci působí na různé tkáně, což vyžaduje jeho citlivost. Cítím, že je strašně důležitý cit pro tkáně... Málo se operují zdravé tkáně, mǔže to být nádor nebo zánět, je to nějaká změna a ten proces někde konči a někde začiná normální tkáň. A vy se musíte pohybovat na té hranici... a ten cit pro tu tkáň, myslím, dělá ty úspěchy. (Ch N) Když se k těm tkáním chováme lépe, jemně, tak ony potom jsou i méně zraněné a mnohem rychleji se hojí. ( $\mathrm{Ch} \mathrm{H}$ ) Cit pro tkáně souvisí s př́močarostí, nesahat tam, kam nemám sahat... Např́klad při operaci $v$ břiše mám jít prímočaře, cílevědomě $k$ tomu, co mám udělat. ( $\mathrm{Ch} \mathrm{L}$ )

Citlivost k tkáním, podobně jako manuální zručnost, předpokládá určité hmatové schopnosti. Někde se očima nedostanete... tak jenom palpačně, prstama, s citem. (Ch D) Chirurg M. uvádí, že až $90 \%$ operací se operuje hmatem, a to přímo nebo prostřednictvím nástrojů. Laparoskopické operace, to je také něco jako hmat, když tím nástrojem hmatám... (Ch B) Při diagnostice chirurgických onemocnění a operacích však nejde pouze o ruce, hmat a zrak, ale také o chirurgovo myšlení. Je to o šikovnosti rukou, ale ten chirurg musí také přemýšlet jako chirurg. (Ch C) V každém prípadě je to schopnost dobrého analytického myšlení... (Ch I)

Rozhodování. Úspěšnost chirurgovy práce je dle mínění dotázaných chirurgů závislá mimo jiné na tom, jak rychle, pružně a kvalifikovaně se rozhoduje. Správný chirurg by měl být schopen během chvíle se rozhodnout... (Ch E) Rozhodování je významné nejenom při operacích, ale také v diagnostickém uvažování, které bývá často složité. I v našem týmu vidíme kolegy, kteří nechtějí dělat těžké, zásadní rozhodnutí. (Ch $\mathrm{CH})$ Dobrý chirurg je ten, který ví, kdy má operovat, ale skvělý chirurg je ten, který ví, kdy neoperovat. (Ch G) Rozhodování o tom, zda pacienta operovat, či neoperovat, představuje odborné, ale často i etické dilema. Odpověd' na tuto otázku vidí jeden mladý chirurg ve dvou směrech. $V$ jednom - u akutních operativ, jestli to slepé střevo je opravdu zanícené... Pak je rozhodování např. u nádorových onemocnění, kde ta prognóza je nejasná... Jestli nechat člověka v klidu odejít, nebo ho zatižit operacemi... to druhé rozhodování je na podkladě etického dilematu. (Ch E) Někdy se chirurg setkává $s$ tím, že - přes všechny vymoženosti zobrazovacích metod - se liší závěr plynoucí ze zobrazovacího předoperačního vyšetření a operační nález. Ano, zásadně se mohou lišit, jakkoli si to nepřejeme. Dnes pomáhají endoskopické a jiné vyšetřovací metody. Ale chirurg musí stále porovnávat, zda to sedí, nebo nesedí, a jestli je to $v$ jeho silách, dát to dohromady... Chirurg se musí $v$ nějakém okamžiku rozhodnout, co je proveditelné... (Ch L) 
Je to tedy o průběžném rozhodování, které provází diagnostický i operační děj. Chirurg se vlastně musí rozhodovat neustále a být připraven na to - do určité míry -, že ho něco v průběhu operace překvapí (,zaskoči“). ...např. v případě nádorového onemocnění po otevření břicha zjistíme, že je tam i generalizace. $U$ jiného pacienta se můžeme setkat s anomální tepnou. (Ch E)

Sociálně komunikativní schopnosti a dovednosti. $V$ neposlední řadě přikládají chirurgové velký význam sociálně komunikativním schopnostem a dovednostem. Operování a sociální komunikace jsou dvě na sobě relativně nezávislé oblasti činnosti chirurga. Jsou lidi manuálně nadaní, umí to krásně, neumí pořádně komunikovat, jsou lidi, kteří umí mluvit, ale neumí dobře operovat. (Ch J) Do standardní úrovně se to nauči každý (komunikovat s pacientem), to něco navíc, člověk bud' má, nebo nemá. (Ch E) V diskusích s chirurgy se logicky objevila otázka, jak postupovat, když excelentní operatér není schopen adekvátně komunikovat s pacientem: ...pak musí přijít někdo $k$ tomu pacientovi, který nahradí ten lidský faktor toho operatéra. $(\mathrm{Ch} \mathrm{H})$

Osobnostní vlastnosti. Z osobnostních vlastností chirurgové uvádějí pokoru, trpělivost a obětavost. Pokora je další důležitá vlastnost pro chirurga. Člověk nemůže být ani velký suverén, nemůže být ani podělaný, něco mezitím. (Ch D) Je nás tady spousta mladých, každý by chtěl být na sále... Je důležité být trpělivý, co nejvice toho pochytit a tak nějak být trošku pokorný... (Ch A) U kolegy Z. si vážím obrovské trpělivosti. Protože operovat každý den štítné žlázy, to je velmi náročné. (Ch D) Asi je nezbytná takováto obětavost... Jezdíme na reoperace, když se nám pacienti komplikují, i ve svém volném čase. (Ch E) Některé vlastnosti mají komplexnější povahu, resp. jsou kombinací více dílčích vlastností, např. rozhodnosti, odvahy, prosociálnosti. Významně ovlivňují týmovou práci, kupř. když se při operaci vyskytnou neočekávané situace nebo komplikace. ...je třeba zachovat klid, když nastane nějaká komplikace... nevyvolat paniku... Když se motivuje podle mě pozitivně a je to $v$ klidu -„to zvládneme“ - je to mnohem lepší. A to právě dokáže ten dobrej chirurg. To se nenaučite. $(\mathrm{Ch} \mathrm{H})$

\subsection{Mladí lékaři se učí chirurgii}

Pohled mladých adeptů chirurgie na vlastní učení. Z chirurgů v našem vzorku začínali chirurgové $C$ a D v okresní nemocnici. Já jsem asi měla tu výhodu, že jsem se jako žena dostala na okres, kde jsem se jako rozoperovala. (Ch D) Tato chirurgyně pak přešla na klinické pracoviště. Obecně lze konstatovat, že na klinikách se obvykle dostanou mladí chirurgové na sál méně často než na menších pracovištích. Na těch větších pracovištích se někteři nedostanou na sál i několik týdnů. Tady je to naopak, protože jsme pořád na sále. (Ch D)

Vlastním chirurgickým aktivitám adeptů chirurgie předchází pozorování operací. Někdy nás vypisují na sály jenom na dívání... proto se dívám a sama přemýšlím, co bych ted'ka udělala. (Ch B) Díváním se hodně naučí, to mě překvapilo třeba samotnýho. A pak samozřejmě, když ten nástroj dostane do ruky, musí sám, jo? Musí si to odzkoušet. (Ch A) Potom následuje asistování při operacích. Ono se ríká, že ten 
114 asistent musí být u operace o krok vpřed před operatérem... (Ch D) Musí předvídat, jaký bude další krok operatéra, aby mu mohl aktivně pomoci, např. přidržet tkáň. Obvykle se rozlišuje první asistence a druhá asistence. Předpokládá se, že první asistent bude při operaci aktivnější. Pro mě, abych se co nejvice naučila, je být první asistence... Jsou dobré služby, tam se člověk dostane k první asistenci. (Ch B) Někdy se stane, že operatér přenechá mladému lékaři - asistentovi určitou část operace, za předpokladu, že je k tomu disponován. Mně třeba se občas stane, že starší lékař mě nechá našít tady tu střevní anastomózu... A není to jako úplně jednoduchý. Najednou je to jiná tkáň než kưže, je to jiná jehla. (Ch A)

Mladí chirurgové vzpomínají na svou první samostatnou operaci, za asistence zkušenějšího, atestovaného chirurga. Byla to moje první operace toho slepáku, tak to byl takový silný okamžik. Paní doktorka řekla, že začnu já... bylo to od ní úžasný, protože mne vedla, $v$ chvili, kdy to bylo složitější, tak to prostě převzala... (Ch B) K první samostatné operaci jsem se dostal za půl roku po príchodu na kliniku. Asistent byl zkušený, řekl, řez povedeš tady, přesně mně ukázal, tady se to řízne... (Ch A) Když mi asistuje zkušený chirurg, ríká, píchni tady, vem to víc, vem to níž, to už je moc... (Ch A) Postupně, jak to dostáváte do těch rukou, jako ty nástroje a postupy těch operací... cítíte, že už jste si v některých věcech jistí. (Ch A) Zkušenostmi, pod vedením erudovaných chirurgů, se mladí adepti učí operování, ale i diagnostice. Ale to vyžaduje i hodně teoretických znalostí... Třeba je důležité umět při bolestech břicha vyloučit infarkt. (Ch B) Učení se diagnostikovat chirurgické nemoci a operovat je založeno na opakování těchto činností, na určitém cviku.

Některé úkony musí již začínající chirurg zvládnout rutinně, např. šití. Pak jsem se teda doma učil uzlit. Půjčil jsem si jehly z nemocnice, jehelec a cvičil jsem to na látce a na klice. Abych to dostal trošku do rukou. (Ch A) Při učení začínající chirurgové využívají učebnice i atlasy operací. Když třeba dneska jsem měl vypsanou kýlu jako operatér, tak včera jsem se díval na obrázky v atlase, jak to tam vypadá. Ráno, když jsem jel do práce, tak jsem to taky přečetl, abych si to tak nějak vštípil do paměti. ( $\mathrm{Ch} \mathrm{A}$ ) Kromě atlasu operací mají dnešní chirurgové možnost zhlédnout (i opakovaně) operační postup na videozáznamu. Dnes si může chirurg pustit na internetu video s tou operací. (Ch D) Začínající chirurgové si postupně uvědomují, že každá operace je jiná, nová, i když určité postupy jsou stejné (Ch C). Že je to o té citlivosti, jemnosti preparace, jak to člověk uchopí, jak si to osahá, aby to nezhmoždil (Ch D). A také, že je to hodně o šikovnosti rukou, ale že ten chirurg musí také přemýšlet jako chirurg (Ch C).

Učení chirurgii pohledem zkušených chirurgů. Základní otázka, na kterou zkušení chirurgové odpovídali, byla, zda se chirurgii může naučit každý mladý lékař - zájemce o tuto profesi. Většina dotázaných chirurgů se domnívá, že je to možné, i když za určitých podmínek. Já si myslím, že z deseti lidí, kteří chtějí dělat chirurgii, se to devět může naučit. Když má velkou vůli, velkou snahu a musí mít i dobré učitele... Potom jsou ale lidé, kteří neposlechnou návěští, že nemají dělat chirurgii, ale silou moci ji chtějí dělat, $t i$ jsou potom nešt'astní. (Ch J) Někteří chirurgové se dokonce domnívají, že chirurgii se může naučit i někdo, kdo není tak manuálně zručný. To je 
stejný jako třeba u hudebníka. Jsou hudebníci od boha, téměř neznají noty a hrají brilantně, potom jsou jiní, kteří noty znají, ale musí se k tomu prohrát. (Ch L)

Objevuje se otázka, zda lze u mladého adepta chirurgie poznat, zda se na tuto profesi hodí, nebo nehodí. To poznáte po pár týdnech... to vidíte, jak napríklad vezme ten nástroj do ruky... (Ch N), ...jak s ním (nástrojem) pohne, i když o tom moc neví. (Ch G) To se na těch lidech pozná, jestli jim to půjde... Jak to uchopí, jak spolupracuje, protože někdo ví, kam tu ruku má dát, kde vám to má přidržet, někdo ne. ( $\mathrm{Ch} \mathrm{H}$ ) Další zkušení chirurgové také uvádějí, že se poznají dispozice k chirurgii, ale že to trvá trochu déle. Tak zhruba za několik měsícủ, když mưže začít dělat jednoduché výkony - tak pozná se to. (Ch J) Myslím si, že to lze poměrně rychle, že ta jeho manuální zručnost není až zas tak dobrá... Řádově, řekněme, během toho roku lze nějakým zpưsobem odpozorovat, zdali je manuálně zručný. (Ch I)

Z pohledu zkušených chirurgů je zřejmé, že mladí lékaři se mohou naučit chirurgii $v$ různé míře, např. zvládnou určité operace, ale na složitější již nemají potřebné dispozice. Někdo se k chirurgickým dovednostem dostává obtížně, musí je důkladně nacvičit, jiný má talent a jde mu to mnohem snadněji. Někdo to vydře, pak jsou někteří výborní chirurgové a pak jsou někteří nadprưměrní... Ten talent je tam důležitý. (Ch N) To, jak se z mladého lékaře stává chirurg, záleží však také na př́ležitostech, které na pracovišti dostává, kupř. jak často je vypisován k operacím, jaký druh operací je mu přidělován. Chirurgie je hodně o příležitosti, jestli ji dostanete od vedení... ( $\mathrm{Ch} \mathrm{H})$

\subsection{Zdroje profesního růstu chirurga}

Praxe jako stěžejní zdroj růstu chirurga. Praktickou činnost při diagnostice chirurgického onemocnění, vlastní operaci i v rámci pooperační péče považují chirurgové za hlavní zdroj jejich profesního růstu. Především ten, kdo něco dělá pravidelně, vyprofiluje se a s lepšími výsledky než ten, kdo to dělá občas a je to pro něho trofejní výkon. (Ch L) Tu praxi a znalost terénu vám nikdy nikdo nevezme... Ten cvik tam je. (Ch N) Jeden zkušený chirurg přiznal, že sám vyhledával náročnější operace (Ch K), což mohlo přispět k zdokonalení jeho praktických dovedností.

Někteří chirurgové konstatují, že jejich profesní růst ovlivnilo, když měli možnost vidět při operaci jiné kolegy, např. na jiných pracovištích $v$ tuzemsku a v zahraničí. Vidět operovat druhé a stát s nimi u toho stolu, at' již je to na mateřském pracovišti nebo na stážích. Člověk vidí, jak to dělají, ale vidí i jejich chyby... To, že se vše nepodaři a že chyby dělají i jiní, tak to na mne pưsobí zklidňujícím dojmem, že to $k$ té chirurgii asi patři a že by to člověka nemělo paralyzovat, naopak, že by to mělo být jakýmsi ponaučením, že problém se může vyskytnout, že se z toho můžeme poučit a jít dál. (Ch I) Opakované profesní vidění umožňuje pochopit určitý způsob operace. Když jsem jezdil do ciziny se některé věci učit, tak se díváte na určité věci, a když tam přijedete za rok, tak se díváte na věci úplně jiné. To, co vám dř́ve unikalo, to nyní vidíte. (Ch N) Do chirurgické praxe zaváděné nové postupy a nástroje vedou i zkušené chirurgy k novému učení. My jsme se naučili dobře dělat klasické žlučníky, 
Tabulka 1 Stupně chirurgova profesního růstu

\begin{tabular}{ll}
\hline Stupeň & Charakteristika \\
\hline řemeslo & zvládnutí řemeslné rutiny \\
pravidla & osvojení pravidel diagnostiky i operací \\
růst & zdokonalení v diagnostice a operacích \\
variace & uvědomění si toho, že způsoby operací mohou \\
& být různé, že lze uplatnit rozličné způsoby \\
& operací \\
tvořivost & uplatnění tvořivých nápadů \\
mistrovství & operace náročných případů, řešení \\
& neočekávaných situací \\
souhra & práce v týmu \\
součinnost & vzájemná podpora a spolupráce (novici \\
& a zkušení, lékaři různých oborů) \\
služba & poskytování vlastních dovedností a zkušeností \\
& druhým lidem \\
naplnění & uspokojení z chirurgické činnosti, vyvrcholení \\
& chirurgického bytí \\
\hline
\end{tabular}

a ted' najednou přišlo něco jiného (laparoskopické operace). Koukali jsme na to, museli jsme se to naučit. (Ch K)

I čtením a konferencemi se chirurg vzdělává. Studium literatury stále patří mezi zdroje profesního růstu chirurga. Snažil jsem se stále naučit se nové věci, nelitoval jsem peněz na to, abych si objednal nějaký časopis, nebo času na to, abych si objednával zahraniční práce, po večerech jsem chodil na angličtinu. (Ch F) V současnosti možnosti studovat nové informace poskytuje internet. Sledovat novinky, to je právě výhoda toho internetu, ale člověk to musí titrovat. (Ch G)

Do určité míry se chirurg vzdělává $i$ tak, že připraví a publikuje studie $v$ odborných našich a zejména zahraničních časopisech. Jednak se zdokonaluje $v$ metodologických dovednostech (sbírat informace, a to i výzkumem, uspořádat je do logicky strukturovaného celku), jednak sděluje zájemcům-chirurgům poznatky, které mohou přispět $\mathrm{k}$ jejich vzdělávání. Snažím se psát to, co opravdu dělám... A nepublikovala jsem nějaké vycucané články... (Ch G) Publikování patří zejména k činnostem akademických pracovníků na chirurgických klinikách. Na klinice by měly fungovat dva typy lidí: jedni, kteří jsou vyloženě kariérní a směřuji k habilitaci, popř. k profesuře, a jiní, kteři by měli dosáhnout kvalifikace a potom pokračovat jako vedoucí na menších pracovištích. (Ch L) Nezřídka se však lze setkat s tím, že publikují i chirurgové z menších pracovišt'. My jsme privátní zařízení, jehož hlavním cílem je - nechci to zjednodušit - být prosperující, vydělat peníze majiteli... Publikování je navíc... upozornění na naši práci, a že je to přece jen vklad do soutěže, aby pacienti věděli, že jdou na pracoviště, které se nezajímá jenom o tu bazální chirurgii, ale že sleduje novinky... (Ch N) Na některých pracovištích primáři získávají titul Ph.D. a vedou 
k němu i své kolegy. Já je $k$ tomu vedu, aby to měli všichni, potom, aby měli možnost se habilitovat. (Ch M)

Účast na konferencích patří k již osvědčeným profesním aktivitám chirurgů, které jsou však doplňovány novými formami vzdělávání. Řekl bych, že ten klasický model konferencí již není tak významný, jak býval dříve, protože $v$ dnešní době těch informačních toků je mnoho. Spiše je to o kontaktu s odborným světem. Ted' se klade vice důraz na princip workshopů, kde se předvádí operace, stáže krátkodobé na určitý typ výkonů... (Ch I)

Primáři jako učitelé. Měl jsem štěstí na učitele, každý byl jiný. Pan primář Z. operoval výborně, prakticky neměl komplikace, dělal to, co uměl, to, co měl nacvičené, co nedělal, tak neexperimentoval... Ale krásně operoval a měl úžasné postoje - co dobře vypadá, dobře funguje. Něco na tom je, aby měl chirurg přehled $v$ operačním poli, aby to šlo vrstva po vrstvě... To mne strašně ovlivnilo... (Ch N) Mne primář T. učil hrudní chirurgii. Ted' se hluboce cítím jeho žákem. Neskutečně jemný člověk, který miloval fyziologické operování. Vzpomínám si, když jsem mu říkal, jak to vypadalo $v$ Japonsku (tady chirurg pobýval na stáži v Tokiu) krásně, ale pak jsem mu řekl: Ale musím vám říci, všechno mají fantastické, ale k lidské tkáni se nechovají tak krásně, jak jste mě to vy naučil. Tomu chlapovi normálně vyhrkly slzy do očí. Opravdu jsem dojatý, když si na to vzpomenu... (Ch J)

Primář může učit své kolegy také v průběhu operace. Včera jsme dělali takovou pacientku, které praskla arteria pulmonalis (plicní tepna), byla úplně papírová. Takže jsem to teda potom převzal, na chviličku... Říkal jsem, Jirko (operatér), to musíš vidět, abys věděl, jak to jednou budeš řešit sám... (Ch M) Zajímavou zkušenost sděluje chirurg $\mathrm{K}$, který popisuje, jak při změně primáře musel změnit způsob předoperačního uvažování. Pro mne byl velmi složitý přechod od primáře A k primáři B... Musel jsem změnit uvažování v předoperační přípravě. Svým způsobem to bylo dobré, protože jsem tu medicínu začal vidět $v$ daleko širším pohledu. Zjistil jsem i to, co jsem myslel, že není možný, a ono to možný je, a že to také přináši výsledky. (Ch K)

Sebereflexe jako součást profesního rủstu. Co je tedy stěžejně potřebné, je sebereflexe. A ta sebereflexe, to znamená ochota analyzovat vlastní práci a její výsledky, protože tam najdete chyby nebo nevysvětlitelné postupy a jste schopen o tom povídat, sám sobě připustit, že to nebylo úplné vítězství, tak to dává šanci to podruhé neudělat. (Ch L) Sebereflexe je pro chirurga důležitá nejenom při zpětné analýze operace, ale také před vlastní operací a v jejím průběhu. Já myslím, že nejdůležitější na tom je sebekontrola. Ta schopnost posoudit, zda jsem to schopen udělat. (Ch L) A potom... jak si věřm, jak to unesu, a přitom se musím pořád dívat vlastním výsledkům do oči a kontrolovat, jestli jsem postupoval dobře. (Ch N) Sebereflexe plní funkci zpětné vazby pro další práci chirurga, umožňuje mu kriticky posuzovat výsledky jeho činnosti a usnadňuje mu rozhodování. Má také motivační potenciál, např. když zpětnou vazbu poskytuje pacient. Nebo se potkám s pacientem a on řekne: Paní doktorko, to jsem rád, že vás vidím, vy jste mě tenkrát operovala, vy jste byla na oddělení a já na to rád vzpomínám. (Ch G) Zpětná vazba může působit na chirurga formativně. Chirurgie nás formovala nejen jako chirurgy, ale i jako lidi. (Ch F) 


\subsection{Proces profesního růstu chirurga}

Impulzem ke sběru dat týkajících se této výzkumné otázky byl, jak již bylo zmíněno, pohled zkušeného chirurga (doc. T. Horvátha) na profesní růst chirurga. $V$ jednom z rozhovorů v rámci sdílení výzkumných zkušeností se vrátil k výzkumnému rozhovoru, který s ním o profesi chirurga vedl pedagog, a konstatoval: ...položil jsi mi jednu, třetí otázku, já jsem nemohl spát, protože jsem si říkal, že nad tímto jsem nikdy pořádně nepřemýšlel. (Ch J) Tento chirurg přišel s návrhem modelu procesu profesního růstu chirurga, který zahrnuje deset stupňủ (etap) - viz tabulka $1 . V$ průběhu výzkumu tento model postupně dozrával (Horváth et al., 2017).

$\checkmark$ polostrukturovaných rozhovorech $s$ dalšími chirurgy pedagog zaměřil pozornost i na proces profesního rưstu. Ze získaných dat se podařilo získat př́klady výpovědí chirurgů $\mathrm{k}$ šesti stěžejním stupňům profesního růstu chirurga.

Řemeslo versus umění. Zvládnutí rutiny je předpokladem náročnějších diagnostických a operačních výkonů. Dokonalé osvojení rutinních postupů umožňuje, aby chirurg postupně nalézal vlastní způsoby operování ( $v$ souladu se zavedenými standardními postupy) a tvořivě improvizoval. Někteří, zejména zkušenější chirurgové považují chirurgii za umění. I z historického kontextu vyplývá např., že ranhojiči prováděli mnohé výkony a byli zruční. Možná to je i důvod, proč se to bere jako řemeslo. (Ch E) Ono se ř́ká, že chirurgie je něco mezi uměním a řemeslem... řemeslo se dá naučit. (Ch D) Chirurgie je, možná, trošku specifická v tom, že rutina, kterou získáváte roky, by měla být jenom ten základ, na tom stavíte. (Ch F) Rutina je potřeba, ale myslím si, že chirurgie je daleko více umění než rutina. Rutina je předpoklad každé lidské činnosti. (Ch J) Chirurgie je asi řemeslo i umění. A určitě mezi chirurgy jsou třeba jenom řemeslníci. (Ch B)

Variace. Chirurgové si postupně vypracovávají svůj styl, který jim umožňuje efektivně operovat. Je dramatický rozdíl mezi postupy dvou výborných chirurgů, každý to udělá jinak, ale výsledek je výborný. (Ch J) Někdy se však stává, že i když se dva zkušení chirurgové při stejné operaci řídí týmž předepsaným postupem, výsledný efekt může být do určité míry rozdílný. Chirurg $M$ ř́íká, že to způsobuje elegance, $\mathrm{s}$ jakou je operační výkon proveden. On to musí dělat ze zásady furt stejně, ale když se dostane do situace, která potřebuje řešení, tak musí najít elegantní řešení. Mělo by tam být něco z toho chirurga. (Ch M)

Tvořivost. Někteří chirurgové spojují chirurgii s tvořivostí. Chirurgie je tvořivá, ale myslím si, že operační výkon sám už je hodně rutinní, ale ta diagnostika... to je na tom to tvořivý. ( $\mathrm{Ch} \mathrm{H}$ ) Tvořivě přemýšlející a zkušený chirurg je nucený někdy improvizovat ( $\mathrm{Ch} \mathrm{H}$, Ch K, Ch E). Improvizace je založena na jeho znalostech i schopnostech. Nastupuje obvykle až po vyčerpání standardních postupů. Takže musíme umět improvizovat, protože můžeme narazit na některý věci, který nás nesmí zaskočit... (Ch G) Čím kvalitnější je rutina, tím máš prostor k nějakým improvizacím. (Ch J) Někteři chirurgové mluví také o intuici, která doplňuje tvůrčí myšlení chirurga i jeho odborné znalosti a zkušenosti. Projevuje se obvykle jako pocit nebo tušení, 
které nelze jednoduše vysvětlit: ...mám nějakou intuici, že se tam něco děje, ale není to tam. Přitom tuším, že to tam může být. (Ch G)

Mistrovství. Zkušení chirurgové přiznávají, že se ve své práci setkávají s neočekávanými situacemi. Jdeš po chodbě a říkáš si, jsem tak utahaný. Zazvoní ti tato skřiňka (telefon), přijd' rychle na sál, máme tady naléhavý případ. Jdeš na sál a tam je devatenáctiletý chlapec a má roztržené srdce. Nemáš k dispozici mimotělní oběh a naskakuje ti husí kưže, protože takový př́pad jsi ani neviděl, ani jsi o ničem podobném nečetl, zjišt'uješ, že ta rána v srdci je zakryta krevní sraženinou, která tam drží jen jakýmsi zázrakem - a poklesem krevního tlaku. A v tom je, myslím, takové vyšší mistrovství, taková až otrlost... Tam se pak musíš rozhodnout na základě toho, co máš za sebou. Najednou si vzpomeneš, co jsi viděl tam a onde v té a oné situaci. (Ch J) Takovéto situace bývají pro chirurga stresující. Je to šílená konstelace, protože si říkáš: ...ted' bych měl někoho zavolat, ale nemohu ztrácet čas. Tak se musís soustředit na to, co o tom víš, nikoliv jestli vůbec na to máš. Už nemůžeš přemýšlet o ničem jiném než jak věc okamžitě vyřešit. A zdárně ji vyřešíte díky úžasnému soustředění asistence, instrumentářky a anestezie. (Ch J)

Souhra - práce v týmu. Z výzkumných dat vyplývá, že chirurgie není pouze o šikovných rukou a zručnosti, jak se i v současnosti stále ještě traduje. Je to do jisté míry pravda, avšak chirurgie není o zlatých rukách, to je o týmové práci. Chirurgie je řetěz, jestli v tom řetězu jeden článek selhává, selže celý řetěz. Manuálně a intelektuálně to musí bazálně fungovat. Ale aby to fungovalo tak, aby to dělalo radost pacientům, personálu, aby se těšili do práce, to musí být komplexní způsob spolupráce. (Ch J)

Naplnění. Dotazované chirurgy jejich profese uspokojuje. Operační sál a ambulance člověka naplňují. Chirurgie je krásná. (Ch E) To je tak náročný obor, fyzicky i psychicky, že to člověk musí milovat, aby chodil rád do práce, aby se těšil na ty operace. (Ch C) Chirurgie dává mnohým chirurgům smysl v tom, že mohou svou činností pomoci druhým. Takto to vnímají mladí, začínající i zkušení chirurgové. Dává mi to dobrý pocit, když člověk může pomoci. To je něco, s čím se člověk musí narodit... Ale ten pocit, když se to povede a ten pacient je vděčný, tak mne to naplňuje. (Ch D) ...pocit uspokojení z práce a z toho, že ta práce přináší nějaký výsledek. Že jsme schopni pacientům efektivně, často rychle pomoci... A to, co je zdánlivě banální, když potkáte pacienta po dvaceti letech, operovaného pro nádor, a on je dobrý a řekne, já jsem vám vděčný, tak máte chut' pracovat dál. (Ch L) ...velké uspokojení, velkou radost. Naplnění života. (Ch J) Naplňuje to tomu člověku ten život, který tady tráví. Sice mám tři děti, ale stejně jsem u toho vydržela. (Ch H) Chirurgie je radostná práce, naplňuje mne. (Ch K) Naplňuje, naplňuje mě to. (Ch G)

Jeden zkušený chirurg vyslovil názor, že každý stupeň vyžaduje nějaký čas. Pro každého může být formát toho vývoje různě dlouhý. Mưže to být pár let a může z něho být šikovný chirurg, jenž ví, jakou cestou se ubírat. Jsou lidé, kteři pracují deset a více let, a stále ještě nevíte, jestli z nich opravdu něco bude... (Ch F) Měl jsem kolegu, který byl manuálně velmi zručný, ale na sále nebyl schopný se rozhodovat. U něho se možná ten vývoj zastavil... (Ch F) 


\section{Poznatky z výzkumu a jejich diskuse}

\subsection{Předpoklady pro profesi chirurga}

Chirurgové v našem výzkumu upozorňují na obecnější předpoklady a vlastnosti. Lze je vyjádřit tímto výčtem: manuální zručnost, prostorová představivost, citlivost k tkáním, hmatové schopnosti a kritické oko, analytické myšlení, schopnost rozhodovat ve standardních a zejména v neočekávaných situacích, sociálně komunikativní schopnosti a dovednosti, pokora, trpělivost a obětavost. Uvedené předpoklady se $v$ činnosti chirurga projevuji společně, ve vzájemné kombinaci. Je zřejmé, že v diagnostické a zejména $v$ operační činnosti dochází k propojování její manuální a intelektuální složky. Za spojovací můstek mezi těmito složkami lze považovat rozhodování. Tento poznatek také potvrzuje Marsh (2017, s. 94), který cituje doporučení staršího chirurga mladšímu kolegovi: Víte, samotné operování se naučíte snadno. Ale než budete $v$ mém věku, zjistite, že veškeré potíže pramení z rozhodování.

\subsection{Učení se chirurgii}

Z výpovědí mladých chirurgů vyplynuly tyto kroky jejich učení se chirurgickým dovednostem: pozorování operací - asistování při operacích - samostatné operace pod vedením zkušeného, atestovaného chirurga. Chirurgové považují za významný zdroj jejich učení počáteční krok, kdy pozorují zkušené chirurgy. Opakované pozorování zkušených chirurgů a expertů při operacích je považováno některými autory za jeden z důležitých předpokladů efektivního osvojení senzomotorických dovedností adepta chirurgie; je príležitostí k osvojování vzorců postupů, které nemohou být verbalizovány (Harris et al., 2018). Je zřejmé, že postupy chirurgických výkonů zahrnují jednak explicitní složku (lze je vyjádřit verbálními a obrázkovými instrukcemi) a jednak složku tacitní (implicitní), kterou obvykle nelze verbalizovat (např. práce chirurga s nástroji). Tacitní složku mladý chirurg vidí ( $v$ explicitní podobě), když pozoruje zkušenějšího chirurga při operaci - vidí, co a jak dělá. Zkušenější chirurgové konstatovali, že chirurgii se může naučit každý mladý adept, který disponuje požadovanými předpoklady, má chut' a vưli se učit. Nezastupitelnou úlohu mají $\checkmark$ učení mladých chirurgů jejich zkušení kolegové a vedoucí chirurgického pracoviště. Chirurgové uvedli, že se dá poznat poměrně brzy, zda je - nebo není - mladý lékař vhodný kandidát pro chirurgii.

\subsection{Zdroje profesního růstu chirurga}

Z výzkumných dat lze odvodit poznatek, že stěžejním zdrojem profesního růstu chirurga je jeho praktická činnost, $\mathrm{k}$ jejímuž zdokonalení může přispět sebereflexe. Praktickou činnost doplňují další aktivity, které chirurgové uvádějí. Za upozornění stojí pozorování jiných chirurgů při operacích, at' již na vlastním pracovišti, či jiných tuzemských pracovištích a také na pracovištích zahraničních. Zajímavá může být 
opakovaná návštěva zahraničního pracoviště, kde náš chirurg může vidět eventuální změny $v$ operačních postupech. Zdá se, že profesní růst chirurga může do značné míry ovlivnit primář, popř. přednosta kliniky. Záleží na jeho odborné, ale i komunikační erudici a $v$ neposlední řadě na jeho ochotě pomáhat.

\subsection{Proces profesního růstu chirurga}

Předpokládali jsme, že proces profesního růstu chirurga zahrnuje řadu stupňů. Předložený model procesu profesního růstu chirurga považujeme za hypotetický, přestože jsme některé stupně doložili daty z rozhovorů (viz též obrázek 2). Model vyžaduje další empirické ověřování u vybraných chirurgů, např. prostřednictvím designu případových studií. Již nyní je však zřejmé, že rychlost a kvalita procesu profesního růstu závisí na osobnosti chirurga, ale také na příležitostech, které dostává. Vrat'me se však ještě k některým stupňům procesu profesního růstu pohledem významných českých chirurgů. Čerpáme z jejich autobiografií a biografií. Profesní růst chirurga ve výstižné zkratce charakterizuje Procházka (1989, s. 150):

Za tisíce operačních hodin se jaksi dostal chirurgický prstoklad do krve. A nebyla to jen technická zručnost, jíž jsme se naučili, ale i cit pro tkáň, který nutil zacházet šetrně se strukturami, jimiž se musí někdy chirurg prodírat k podstatě toho, co má úspěšně řešit. I ten nejslavnější pianista se dopracovává k mistrovskému provedení Beethovenovy Appassionaty vytrvalým, trpělivým hraním etud. Cílem není pouze zvládat stále dokonaleji hru prstů, ale i pronikat do duše skladby. Představuji si, že nějak obdobně, každodenní šedivou operační praxí, roste chirurg. Získává tak manuální zručnost a navíc si prohlubuje vědomosti o chorobných jevech, které má operovat. Úroveň chirurga roste také poznáváním důsledků vlastní operační činnosti, kladných, ale hlavně negativních.

Vlastní zkušenosti z diagnostiky a léčby chirurgických nemocí jsou jedním z významných akcelerátorů chirurgova profesního růstu. Hájek (2011, s. 197) konstatuje, že

operační techniku určitého výkonu může bystrý lékař ovládnout již po několika týdnech, ale nedokáže ještě přesně odhadnout rưznou povahu a pokročilost chorobného procesu a neumí se tak orientovat jako starší operatér, protože nemá dostatek vlastních zkušeností.

Z výzkumných dat je zřejmé, že chirurgové se dopracovávají do různé úrovně dokonalosti, a to nejenom v závislosti na délce chirurgické praxe, ale i osobnostních předpokladech. Nahodil (2017, s. 37-38) tuto skutečnost demonstruje třemi základními typy chirurgů: 1) chirurgové, kteří poznali náročnost a obtížnost profese a nedokázali se s touto skutečností vyrovnat a obvykle odcházeli do méně náročných oborů; 2) chirurgové, kteří se dopracovali „do průměru“, jsou schopni realizovat méně náročné operace; 3 ) chirurgové, kteří zvládli i náročnější operace. 


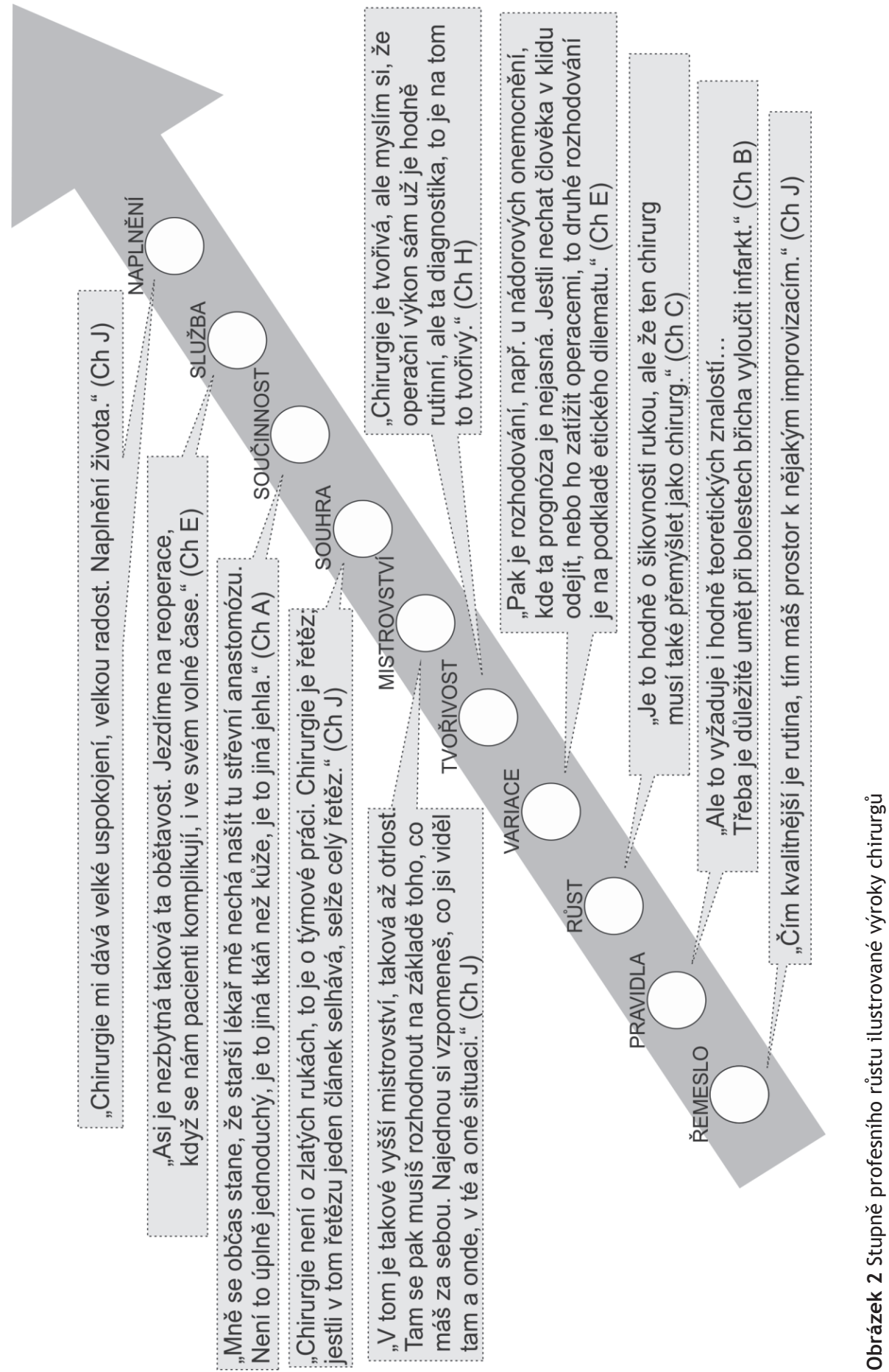


Výzkum odpověděl na čtyři položené výzkumné otázky (viz kapitola 4). Odkryl místa $\checkmark$ profesi chirurga pohledem těch, kteří toto povolání prakticky vykonávají. Především popsal základní předpoklady, které by měl chirurg splňovat. Na těchto předpokladech se shodli chirurgové s rozdílnými chirurgickými zkušenostmi. Z těchto předpokladů se odvíjí profesní růst chirurga, který zahrnuje řadu stupňů (etap). $\checkmark$ našem výzkumu jsme navrhli model desetistupňového (desetietapového) procesu profesního růstu chirurga a částečně jej ověřili daty z rozhovorů. Tento model umožňuje posoudit, jak daleko se chirurg v profesním růstu dostal. Délka jednotlivých etap je závislá na řadě okolností - především na osobnosti chirurga (tedy i na tom, jak splňuje základní předpoklady), na př́ležitostech, ke kterým se na pracovišti dostává, a v neposlední řadě na odborném vedení (zkušeným chirurgem, primářem apod.). Může se stát, že na některém stupni zůstává chirurg př́liš dlouho, ale pak pokračuje dál (např. po „natrénování“ základních rutinních postupů). V jiném př́padě chirurg není schopen dalšího profesního růstu nebo z profese odchází. To jsou však hypotetické př́pady, které je žádoucí, podobně jako celý model procesu profesního růstu, dále empiricky ověřovat.

Náš výzkum měl mezioborový charakter, který jsme popsali. Mezioborovost je založena na sdílení poznatků pedagoga a chirurgů při príípravě, realizaci a vyhodnocování výzkumu. Předpokládá, že odborník jednoho oboru (pedagog, chirurg) vidí přes hranice svého oboru do oboru druhého. Výsledky výzkumu profese chirurga však mají své limity. Patří k nim užší záběr výzkumných otázek i to, že se na výzkumu podílel pouze jeden výzkumník - pedagog. Na druhé straně to, že výzkumná data analyzoval výzkumník obeznámený s profesí chirurga a že je konzultoval se spolupracujícími chirurgy, umožnilo získat výsledky, které odpovídají realitě profese chirurga.

Výsledky výzkumu mohou podle našeho mínění nalézt širší uplatnění. Mohou sloužit mladým lékařumm po absolvování lékařské fakulty (nebo studentům ve vyšších ročnících studia) - jako jeden ze zdrojů - při výběru oboru, kterému se chtějí věnovat. Výsledky výzkumu umožní motivovaným chirurgům reflektovat vlastní chirurgickou činnost. Pro lékaře jiných odborností se výsledky výzkumu mohou možná stát zajímavou informací, jak chirurgové vidí svoji profesi. Pro pedagogickou odbornou veřejnost je popsaný výzkum jedním z př́kladů realizace mezioborových aktivit pedagogů a představitelů jiných profesí.

\section{Literatura}

Balaš, V., \& Vlček, J. (1988). Akademik Arnold Jirásek - český chirurg. Praha: Avicenum.

Barber, P., \& Brownell, P. (2011). Kvalitativní výzkum. In P. Brownell a kol., Gestaltterapie: teorie, výzkum a praxe (s. 54-87). Praha: Triton.

Géringová, J. (2011). Pomáhající profese - tvořivé zacházejí s odvrácenou stranou. Praha: Triton.

Hájek, M. (2011). Chirurgovy úspěchy a zklamání. Praha: Galén. 
124 Harris, D. J., Vine, s. J., Wilson, M. R., McGrath, J. S., LeBel, M.-E., \& Buckingham, G. (2018). Action observation for sensorimotor learning in surgery. British Journal of Surgery, 105(13), 1713-1720.

Hoch, J. (Ed.). (2007). Niederlovské reminiscence. Praha: Akropolis.

Horváth, T., Švec, V., Moravčík, P., Španková, M. , \& Kala, Z. (2017). Půvab chirurgie (Rukopis). Brno: LF a PdF MU.

Koutná Kostínková, J., \& Čermák, I. (2013). Interpretativní fenomenologická analýza. In I. Čermák, T. Řiháček, R. Hytych a kol., Kvalitativní analýza textů: čtyři př́stupy (s. 9-43). Brno: MU.

Křižová, E. (2006). Proměny lékařské profese z pohledu sociologie. Praha: SLON.

Marsh, H. (2017). Neubližíš: Fascinující přiběhy lékaře, který operuje lidské mozky. Brno: BizBooks.

Nahodil, V. (2017). Vzpomínky chirurga. Praha: Karolinum.

Nolin, J. (2008). In search of a new theory of professions. In Science for the professions (s. 9-49). University of Borås. Report No. 4.

Pafko, P. (2004). Medicínmani a ti druzí. Praha: Nakladatelství Lidové noviny.

Procházka, J. (1989). Ze vzpomínek chirurga. Praha: Práce.

prof. PhDr. Vlastimil Švec, CSc.

Institut výzkumu školního vzdělávání Pedagogická fakulta, Masarykova univerzita Poříćí 31, 60300 Brno svec@ped.muni.cz

doc. MUDr. Teodor Horváth, CSc. Chirurgická klinika, Fakultní nemocnice Jihlavská 20, 62500 Brno horvath.teodor@fnbrno.cz

MUDr. Petr Moravčík Chirurgická klinika, Fakultní nemocnice Jihlavská 20, 62500 Brno moravcik.petr@fnbrno.cz

MUDr. Markéta Španková

Chirurgická klinika, Fakultní nemocnice Jihlavská 20, 62500 Brno spankova.marketa@fnbrno.cz

prof. MUDr. Zdeněk Kala, CSc.

Chirurgická klinika,

Fakultní nemocnice Jihlavská 20, 62500 Brno kala.zdenek@fnbrno.cz 


\section{Příloha - Systém kategorií}

1 Chirurgovy předpoklady pro jeho úspěšnou činnost

1.1 Základní psychomotorické schopnosti a dovednosti

1.1.1 Manuální zručnost

1.1.2 Prostorová představivost

1.1.3 Citlivost k tkáním

1.1.4 Hmatové schopnosti

1.1.5 Myšlení

1.2 Rozhodování

1.2.1 Rychlé rozhodování

1.2.2 Rozhodování: operovat $\times$ neoperovat

1.2.3 Rozdíl: předoperační a operační nález

1.2.4 Situace, které překvapí

1.3 Sociálně komunikativní schopnosti a dovednosti

1.3.1 Schopnosti operovat versus schopnosti komunikovat

1.3.2 Malá schopnost komunikovat

1.4 Osobnostní vlastnosti

1.4.1 Pokora

1.4.2 Trpělivost

1.4.3 Obětavost

1.4.4 Kombinace vlastností

1.4.5 Schopnost zachovat klid

2 Učení se chirurgii

2.1 Pohled začínajících chirurgů

2.1.1 Začátky: okres versus kraj

2.1.2 Pozorování operací

2.1.3 Asistování při operacích

2.1.4 První samostatná operace

2.1.5 Učení se diagnostice

2.1.6 Cvičení $v$ dovednostech

2.1.7 Rutina

2.1.8 Atlas operací a videozáznam

2.1.9 Uvědomění si rozdílnosti operací

2.2 Pohled zkušených chirurgů

2.2.1 Naučitelnost chirurgie

2.2.2 Poznání předpokladů pro chirurgii

2.2.3 Individuální rozdíly mezi adepty chirurgie

2.2.4 Př́ležitosti

3 Zdroje profesního růstu

3.1 Praxe

3.1.1 Pravidelnost 


\section{$126 \quad 3.1 .2$ Cvik}

3.1.3 Vidět při operaci druhého

3.1.4 Učení se novým postupům

3.2 Studium a konference

3.2.1 Studium literatury

3.2.2 Publikování

3.2.3 Konference

3.3 Primář jako učitel

3.3.1 Rozdílnost primářů

3.3.2 Učení při operaci

3.3.3 Změna primáře

3.4 Sebereflexe

3.4.1 Analýza vlastní práce

3.4.2 Sebekontrola

3.4.3 Zpětná vazba

3.4.4 Formativní vliv

4 Proces profesního růstu chirurga

4.1 Řemeslo versus umění

4.2 Variace

4.3 Tvořivost

4.4 Mistrovství

4.5 Souhra - práce $v$ týmu

4.6 Naplnění 